\title{
TEACHER'S POSITIVE POLITENESS STRATEGIES IN EFL CLASSROOM: A QUALITATIVE DESCRIPTIVE STUDY AT AN ENGLISH COURSE IN MAKASSAR, INDONESIA
}

\author{
Haryanto Atmowardoyo - Sukardi Weda - Nurmawati
}

doi: $10.18355 /$ PG.2020.9.2.10

\begin{abstract}
Abstact
In the teaching learning process in the classroom setting, the harmonious relationship between teachers and students in the classroom is the cornerstone for achieving learning goals. This study aims to explore teacher's positive politeness strategies in EFL classroom interaction. In this present study, one conversation class at an English course in Makassar was recorded and observed by the reseachers to find out the positive politeness strategies employed by teacher and students in the classroom. The classroom interaction is transcribed, and analyzed through coding. The strategies of positive politeness can be seen in three sections of the teacher's activities in the classroom, pre teaching, whilst teaching, and post teaching. The findings show that there are 2 (two) positive politeness strategies in pre teaching: Asking A Persuasive Question and Greeting The Students As In-Group Membership. In the whilst-teaching 9 (nine) strategies are detected: Reviewing the Last Subject Using Motivating Expressions; Encouraging The Student Coming Late; Letting The Students Coming Late Take A Seat Using "Please"; Addressing Students "Guys" And "We/Let's"; Checking The Students' Understanding Using Polite Questions; Building Students' SelfConfidence; Giving A Funny Example; Giving instruction Using "please"; and Using A Polite Expression "Could you please ...." instead of "Can you ....." In the post teaching stage, 6 (three) strategies are found: Using Appreciating Expressions; Praising Student's Comment; Expressing disagreement in a polite expression; Replying Students' Answers without No; Telling the Next Activity using "Let's"; and Giving Homework as a "Gift" . These strategies contribute to create effective interaction between teacher and students, and students and students.
\end{abstract}

\section{Key words}

teacher's positive politeness strategies, EFL classroom, pre teaching, whilst teaching, post teaching

\section{Introduction}

The presence of language as a means of communication among social beings in society is very important and a necessity. According to Noddings (1995), through language, each individual can adjust to the physical and social environment, also can learn the habits, culture, customs, and backgrounds of each. Therefore, as social beings, humans are expected to be able to use language and language symbols appropriately, so that communication or interaction can be mutually beneficial. This is done to maintain good social relations and interactions. 
In communication, rules are needed that govern the speaker and interlocutor so that good communication can be established between the two. One of the rules that need to be considered is the politeness of language when communicating with other humans. In general, politeness is a matter related to subtlety and goodness; not only good behavior, but also good speech in accordance with the norms prevailing in society.

According to Leech (1983) politeness especially in verbal communication can be seen in several indicators. One of them is the politeness maxims contained in utterances. Leech divides the principles of politeness into six maxims, namely the maxim of wisdom, the maxim of generosity, the maxim of appreciation, the maxim of humility, the maxim of consensus, and the maxim of sympathy.

English Courses as nonformal educational institutions have a strategic role in shaping students' politeness. One of the social interaction activities at a professional course is teaching and learning activities. The success of the teaching-learning process in the classroom is determined by several factors. One of the determining factors is the application of the positive politeness principle between students and teachers, and between students and other students. Therefore, teachers and students pay attention to the principle of positive politeness in communication and interaction in the classroom.

The application of positive politeness principles is very important in classroom interactions. The principle of positive politeness used in the classroom has an important role in the teaching-learning process in the school and becomes the basis (connerstone) for the formation of good student character. The polite language can make the learning atmosphere stay controlled and comfortable. Sulu (2015) states that "politeness is considered to promote effective interactions between people." Politeness can promote positive interactions between humans.

Referring to the issue of the positive politeness' role in the classroom, the researchers observe and analyze the use of positive politeness strategies to create effective interactions in the teaching-learning process in the classrooms of one of the English course in Makassar. With this argument, the study is conducted to answer the research questions as follows: "What politeness strategies do the teachers use to create effective classroom interactions?

\section{Positive Politeness}

Lakoff (1973) and Leech (1983) believe that politeness is a principle to maintain togetherness in communication to avoid conflicts that might occur. The principle of politeness is used in communicating so that the communication runs smoothly. By applying the principle of politeness, messages or ideas can be received and understood. The principle of politeness will lead to comfort and openness.

The theories of Lakoff and Leech above were refined by Brown and Levinson (1987) with the theory of the concept of facial wants. The core of this theory is to save the face (face threthening act) of the speech partner, the speaker selects the speech based on three social factors, namely social 
relations, the strength of symmetrical relationships, and the rating scale of emphasis, as outlined in the face threathening act (FTA).

Brown and Levinson continue Goffman (1967) about facial concepts and propose two types of faces, namely positive and negative faces. A positive face is an individual's desire to be valued and accepted by others. A negative face is an individual's need to have freedom to act or behave without being pressured. Politeness theory as stated by Brown and Levinson is a tool to describe the quality of social relations. They present a universal rationalist theory of the application of politeness strategy as the main principle of using language in social interaction.

In line with Brown and Levinson's theory, Yule (1996) provides a definition of the face (face). The face is a personal attribute possessed by every human being that is universal. Attached to the face is a social attribute that is self-esteem, an award given by the community, or individually owned. The face is a "community loan," as an academic degree that is given by a college, which can be withdrawn at any time by the giver. Therefore, the owner of the face must be careful in behaving, including in language.

Sülü (2015) also indicates that politeness that grows in the classroom can encourage the birth of mutual understanding and harmonious relations between teachers and students. Politeness also contributes to the establishment of effective interactions and friendly atmosphere in the classroom. Teacher politenes helps students to have positive feelings towards the lesson and motivates them to participate more in class.

\section{Method}

This research uses qualitative descriptive methods especially conversation analysis. A descriptive research method is designed to describe the existing phenomena as accurately as possible (Atmowardoyo, 2018). As a qualitative research, verbal data are used as the evidences for formulating description. Qualitative research is research that investigates the quality of relationships, activities, situations, or material (Bogdan \& Biklen, 1982). This research is a qualitative descriptive study with natural settings as a direct source of data where the researchers take the role as the main instrument. There are two techniques used in collecting data, namely observation and interview.

In this study, researchers use a qualitative descriptive method to describe the types of politeness strategies used by the teacher in promoting effective classroom interaction in a an English Conversation class. This research was carried out in 3 months from May 1 until August 30, 2019 in an English Course in Makassar, Indonesia.

Data analysis is conducted through coding adopted from Strauss and Corbin (1990). The coding process covers three interactive stages: open coding, axial coding, and selective coding. Open coding is carried out by identifying and labeling the verbal data related to the research focus of politeness strategies. With axial coding, similar data are grouped into categories. And with selective coding, the revealing categories are narrated in a theoretical description. As a result, the data obtained from this study are 
presented in three stages: pre-teaching, whilst-teaching, and post-teaching sections.

\section{Findings}

The result of data analysis shows 17 (seventeen) types of politeness strategies used by the teacher: 2 (two) types in pre-teaching; 9 (nine) types in the whilst-teaching; and 6 types in the post-teaching sections. In order to be readable, these types of strategies are presented in the tables below.

\subsection{Politeness Strategies in Pre-Teaching}

Two different strategies were identified in the pre teaching section. The types of politeness strategies in this section are described in Table 1.

Table 1: Types of Politeness Strategies in Pre-Teaching

\begin{tabular}{|l|l|}
\hline $\begin{array}{c}\text { TYPE OF POLITENESS } \\
\text { STRATEGIES }\end{array}$ & \multicolumn{1}{c|}{ VERBAL DATA } \\
\hline $\begin{array}{l}\text { Opening the class by } \\
\text { Asking a persuasive }\end{array}$ & Excerpt 1: \\
question & SS : Noisy ) \\
& SS : Well, can we start the class? \\
& T : Ok thank you so much for your \\
& understanding, how are you today? \\
& SS : Fine mam and you? \\
& T : Alhamdulillah good, So last meeting \\
& do you still remember our subject? \\
\hline Greeting the Class & Excerpt $2:$ \\
& T: Well. Good afternoon class \\
& SS : good afternoon Mam \\
& T : How are you today? \\
& SS: Fine \\
& T : Are you ready to study? \\
& SS : Yes we are ready \\
\hline
\end{tabular}

\subsubsection{Opening the Class by asking a persuasive question}

Table 1 shows two different strategies in the pre teaching section. The first, the subject opens the class by asking a persuasive question. In the Excerpt 1, the situation was in the beginning of the class, when the teacher wanted to begin the class and found that the students were still busy with their talk. Instead of saying "Don't be noisy!" or "Be silent please!" which can make the students felt guilty and uncomfortable, the teacher preferred to say in polite way by saying "Well, can we start the class?". The students then became silent, so the teacher continued greeting the students by saying "How are you today'? and the students replied "Fine Mam, and you?". The 
way the teacher made the students be quiet indicated that the teacher tried to make the situation become friendlier and tried to make the students cooperate with her. Similarly, referring to the students respect by saying "Mam", it can be said that students gave good cooperation and felt close to the teacher as well. It indicates that both teacher and students have a good emotional relationship.

\subsubsection{Greeting the Class to make students be ready for class}

In the Excerpt 2, the teacher began her class by using greeting " good afternoon" and then called her students with "class" which can be classified as in-group membership. The sudents gave a positive response by calling "Mam". After that, the teacher continued the class by giving some questions " how are you today? " and "are you ready to study? " that could made the students participate and be active in the classroom. The use of the utterance " class " is one of polite way of the teacher to greet her students. Calling class instead of " students" or " children " shows that the teacher tent to keep students at a distance. Meanwhile, to drag the students participation, the teacher gave the questions that for sure the students would answer it. Those examples of questions were made by the teacher in order to give opportunities to the students to paticipate in learning process and it can be classified as a polite strategy of the teacher.

\subsection{Politeness Strategies in Whilst-Teaching}

Table 2: Types of Politeness Strategies in Whilst-Teaching

\begin{tabular}{|c|c|}
\hline $\begin{array}{c}\text { TYPES OF } \\
\text { POLITENESS } \\
\text { STRATEGIES }\end{array}$ & VERBAL DATA \\
\hline $\begin{array}{lr}\text { Reviewing } & \begin{array}{r}\text { Last } \\
\text { Subject }\end{array} \\
\text { using } \\
\text { motivating } & \\
\text { expressions } & \end{array}$ & $\begin{array}{l}\text { Excerpt } 3 \text {; } \\
\mathrm{T}: \text { oh good, event in the past and still relate } \\
\text { now. Anything else, others? You must } \\
\text { still remember the characteristic of } \\
\text { present perfect, right? } \\
\mathrm{SS}: \text { yeah, hm maybe hahahahha } \\
\mathrm{T}: \text { so what? } \\
\mathrm{S} 1 \text { : use verb } 3 \\
\mathrm{~T}: \text { that's very good. What else? Before verb } 3 \\
\text { what should we put? Do you know? } \\
\text { Remember? Forgot? No idea? ok } \\
\text { thank you } \\
\mathrm{SS}: \text { ( laughing ) } \\
\mathrm{S} 2 \text { : hmm I know have or has }\end{array}$ \\
\hline
\end{tabular}




\begin{tabular}{|c|c|}
\hline $\begin{array}{l}\text { Encouraging the } \\
\text { student } \\
\text { comes late }\end{array}$ & $\begin{array}{l}\text { Excerpt 4: } \\
\mathrm{T}: \text { Who is that ? come in please } \\
\mathrm{S} 3 \text { : Excuse me Mam } \\
\mathrm{T}: \text { Whooo you are so awesome, wearing } \\
\text { hat } \\
\mathrm{S} 3 \text { : I am sorry mam I am late } \\
\mathrm{T}: \text { No worries, so what's you reason ben? } \\
\mathrm{S} 3 \text { : My reason, hmm my reason is you. You } \\
\text { are my reason hehehe } \\
\mathrm{SS} \text { : Whoooo } \\
\mathrm{S} 1 \text { : Kayak yg penyanyi itue, siapa lagi? ( like } \\
\text { that singer, do yo know?) } \\
\mathrm{S} 2 \text { : Calum scott }\end{array}$ \\
\hline $\begin{array}{l}\text { Letting the Student } \\
\text { who comes late Sit } \\
\text { Down using "please" }\end{array}$ & $\begin{array}{l}\text { Excerpt } 5: \\
\mathrm{T}: \text { We all understand you heheh, thank you } \\
\text { and you may have a seat please } \\
\mathrm{S} 3: \text { thank you for your kind attention } \\
\mathrm{S} 2: \text { woow clap hands dong } \\
\mathrm{SS}: \text { hahahhaha }\end{array}$ \\
\hline $\begin{array}{l}\text { Telling About The } \\
\text { Next Activity by } \\
\text { addressing " } \\
\text { students "guys" } \\
\text { and "we/let's" }\end{array}$ & $\begin{array}{l}\text { Excerpt } 6 \text { : } \\
\mathrm{T}: \text { ok, so now we are going to do reading } \\
\text { activity ya. I have already prepared one } \\
\text { text here and in this text you can see the } \\
\text { example of present perfect sentence. As } \\
\text { usual I want you guys read it first and } \\
\text { after that we discuss the difficult words. } \\
\text { Excerpt } 7 \text { : } \\
\mathrm{T}: \text { Now, let's do the next activity. I want } \\
\text { you guys make the sentences from the } \\
\text { words in the bold but it must be based } \\
\text { on your experience. Remember ya every } \\
\text { sentences you have to put for, since, } \\
\text { always, or never. Is it clear? }\end{array}$ \\
\hline $\begin{array}{l}\text { Checking the } \\
\text { students' } \\
\text { understanding } \\
\text { using polite } \\
\text { questions }\end{array}$ & $\begin{array}{l}\text { Excerpt 8: } \\
\text { T : so any difficult words for you? Or I beg } \\
\quad \text { you have understood all the words, } \\
\quad \text { don't you? } \\
\text { SS : ohhh no mem, a lot } \\
\text { S2 : approximately mem } \\
\text { S3 : sekitar, atau kira kira } \\
\text { S1 : dormitory mem } \\
\text { S3 : asrama }\end{array}$ \\
\hline
\end{tabular}




\begin{tabular}{|c|c|}
\hline $\begin{array}{l}\text { Building } \\
\text { students' } \\
\text { confidence }\end{array}$ & $\begin{array}{l}\text { Excerpt 9: } \\
\mathrm{S} 1: \text { Pay phone Mam apa? ( what is pay phone } \\
\text { Mam?) } \\
\mathrm{T}: \text { Ah Fadel, you must have known this } \\
\mathrm{S} 2 \text { : bukan telepon umum mam (it is pubic } \\
\text { telephone, isn't it?) } \\
\mathrm{T}: \text { yah it is ............ }\end{array}$ \\
\hline $\begin{array}{l}\text { Answering } \\
\text { Student's } \\
\text { Question } \quad \text { By } \\
\text { Giving A Funny } \\
\text { Example }\end{array}$ & $\begin{array}{l}\text { Excerpt } 10 \text { : } \\
\mathrm{S} 1: \text { Mem bisa kasi contoh dulu, misalnya ini } \\
\text { mem kata have disini jadi bagaimana } \\
\text { itu? ( can you give an example Mam? } \\
\text { Like the word of have mam, what should } \\
\text { we do? ) } \\
\mathrm{T}: \text { nah ingat kan kalau perfect pakai verb } 3 \\
\text { jadi have itu di ubah dulu ke verb } 3 \text {, apa } \\
\text { verb } 3 \text { nya have? ( nah remember if } \\
\text { present perfect using V3 so you should } \\
\text { change have into V3. Do you know what } \\
\text { is the V3 of have?) } \\
\mathrm{S} 2: \text { had } \\
\mathrm{T}: \text { good, jadi misalkan kalimatnya I have } \\
\text { had 10 exboyfriends since junior high } \\
\text { school. Ingat ya harus berdasarkan } \\
\text { pengalaman sendiri. ( good, you can } \\
\text { make the sentence like I have had } 10 \\
\text { exboyfriends since junior high school. } \\
\text { Remember, it must be based on your } \\
\text { experience) } \\
\mathrm{S} 3: \text { uhh sedikit itu mem, saya sdah selusin } \\
\text { hahahha ( uhh it is just a few mam, I } \\
\text { have already had a dozen hahahha) }\end{array}$ \\
\hline $\begin{array}{l}\text { Giving } \\
\text { instruction Using } \\
\text { "please" }\end{array}$ & $\begin{array}{l}\text { Excerpt } 11: \\
\mathrm{T}: \text { nah here are some of expressions that } \\
\quad \text { commonly used when make a phone. } \\
\quad \text { Please take the paper. } \\
\text { SS : Thank you mam }\end{array}$ \\
\hline $\begin{array}{l}\text { Checking } \\
\text { students answer } \\
\text { using a polite } \\
\text { expression } \\
\text { "Could } \\
\text { " you }\end{array}$ & $\begin{array}{l}\text { Excerpt 12: } \\
\mathrm{T} \text { : The next number? Dewi could you please } \\
\text { share your answer? } \\
\mathrm{S} 1: 9936606 \text {. Coockmi mem? ( is that }\end{array}$ \\
\hline
\end{tabular}




\begin{tabular}{|c|c|}
\hline $\begin{array}{l}\text { please } \\
\text { instead of "..." Can } \\
\text { you ....." }\end{array}$ & $\begin{array}{c}\text { correct mam ?) } \\
\mathrm{T}: \text { yeah almost correct. It is } 9996646 . \\
\mathrm{S} 1: \text { Oh } 4 \text { kah Mem, saya dengarnya seperti } \\
\text { bilang oh ( oh, is it } 4 \text { mam?, I heard it is } \\
\text { like pronounce o ) }\end{array}$ \\
& $\begin{array}{c}\mathrm{T}: \text { No worries, What is the last number? Who } \\
\text { wants to try ? fadel could you? } \\
\mathrm{S} 2: \text { of course mam, it is } 2119349\end{array}$ \\
\hline
\end{tabular}

Table 2 shows 9 (nine) types of politeness strategies used by the teacher as the research subjects during the whilst-teaching section.

\subsubsection{Reviewing Last Subject using motivating expressions}

In the Excerpt 3, the teacher reviewed the last subject Present Perfect Tense. To check her students knowledge, she did not directly ask her students the question about the formula of present perfect, but she prefered to say " you must still remember the characteristic of Present Perfect Right? " This caused the students feel motivated and cooperate to remember what has already been taught. The students' motivation can be seen from their response which means they felt optimistic to remember it and finally they could answer the question. Anoher polite strategy to review about perfect tense was making a joke to the students. It can be seen from the utterance from the teacher " before verb 3 what should we put? do you know? Remember? forgot? No idea? Ok thank you". The teacher said that question fast with the exaggerated intonation and stress that made the students laugh. The situation become relaxed and the students answered the question without pressure.

\subsubsection{Encouraging the student who comes late}

In Excerpt 4, one of the students came late to the class. When he entered the class, the teacher noticed that there was something different in his appereance and said "whoo you are so awesome, wearing hat". Instead of being angry or giving punishment to the late student, she tried to made her student not feeling embrassed or shy by saying polite comment. That comment caused the student felt confidence to enter the class and asked apologise. She then continued to ask the reason by calling her student using his nick name " so what's your reason Ben?" which can be categorized as a politeness way of the teacher where she positioned herself like a friend. This emphasises that the teacher did not position herself as the most powerful agent in the class. Calling her student with nick name could influence the student's confidence. It can be seen from the response of the student in giving reason. He then so confidence gave a reason by copying one of the song and it caused his friends being involved in that conversation. It can be said that the teacher has already made the interaction among them became effective and lively. 


\subsubsection{Letting the student who comes late Sit Down using "please"}

In Excerpt 5, the situation was in the middle of the learning process. One of the student came late. After giving the reason, the teacher then asked him to sit by saying "thank you and you may have a seat please". The way of her asking in polite way to sit can be classified as politeness strategy of the teacher where she uses the polite expression of asking someone to do something instead of using imperative sentence. By the use of that expression, the late students felt appreciated and it could manage his nervousness where it can be seen from his response by saying thank you to his teacher.

\section{2.4 Addressing Students "guys" and "we/let's"}

In Excerpt 6, the teacher was telling about the next activity. The use of word "we" which reflects to the teacher and students can be classified of polite way of the teacher where she includes her self in that activity. Meanwhile, the teacher used the word "guys" to call her students which could reduce the possibility of face threatening caused by activities given like reading and discussing the text. In Excerpt 7, the teacher said "let's" which reflects as polite way. To motivate the students to do the next activity is by including her self in the activity in order to get the students' understanding and cooperation. The use of word "let's" can minimize the situation, therefore, it can motivate the students to do the next activity.

\subsubsection{Checking the students' understanding using polite questions}

In Excerpt 8, the students have just finished doing reading activity. To know how many difficult words still not understood, the teacher asked them in polite way by saying " I beg you have understood all the words, don't you?" and therefore, made the students did not feel shy to share the words that still made them confused. The use of question tag in asking is a signaled of politeness of the speaker.

\subsubsection{Building students' self-confidence}

Excerpt 9 shows the use of positive politeness used by the teacher. After reading activity, one of the student asked about the meaning of word still confusing. Before the teacher answered it by herself, she gave the chance to the student whom she believed could answer it. She said " Ah Fadel, you must have known this ". The use of that utterance indicates that teacher noticed one of the student is smart and tried to satisfied the student by mentioning his name. In this case the teacher has apllied positive politeness strategy where she maintains her students positive face. By using that expression, she made the student feel confident and be brave to talk.

\section{2.7 Answering Student's Question By Giving A Funny Example}

In the Excerpt 10, the students were doing the exercises. One of the students was asking an example how to construct the sentence. When giving an example, the teacher made the funny sentence "I have had 10 exboyfriends since Junior High School". The use of joke in this situation 
showed the teacher's good manner as indicator of politeness where the joke was used to acquire attention of the students and made the teaching learning process became fun.

\subsubsection{Giving instruction Using "please"}

Excerpt 11 shows the use of "please" as a positive politeness. This expression was meant to be polite in giving instruction. The use of that utterance in asking or ordering something is categorized as a polite way to soften the flow of the interaction and maintain the good communication in the class.

\subsubsection{Checking students answer using a polite expression "Could you please ...." instead of " Can you ....."}

In Excerpt 12, the teacher checked the students' answers after doing listening activity of phone number. She then asked the students using polite questions by saying "Dewi could you please share your answer" and " Fadel could you". The use of word could instead of can in asking something to do is a signaled of politeness of the speaker. The teacher could be less polite if she directly asked the students to answer. As the most powerful agent in the class, the teacher has shown a good manner in asking someone to do something.

\subsection{Politeness Strategies Used in Post-Teaching}

Table 3: Types of Politeness Strategies Used in Post-Teaching

\begin{tabular}{|c|c|}
\hline $\begin{array}{c}\text { TYPES OF POLITENESS } \\
\text { STRATEGIES }\end{array}$ & VERBAL DATA \\
\hline $\begin{array}{l}\text { Evaluation } \quad \text { Using } \\
\text { Appreciating } \\
\text { Expressions }\end{array}$ & $\begin{array}{l}\text { Excerpt } 13 \\
\mathrm{~T} \text { : so what? } \\
\mathrm{S} 1 \text { : use verb } 3 \\
\mathrm{~T} \text { : that's very good. What else? } \\
\text { Before verb } 3 \text { what should we put? } \\
\text { Do you know? Remember? } \\
\text { Forgot? No idea? ok thank you } \\
\mathrm{SS}: \text { ( laughing ) } \\
\mathrm{S} 2: \text { hmm I know have or has } \\
\mathrm{T}: \text { Excellent. So remember if you want } \\
\text { to construct present perfect you have } \\
\text { to put have/has after the subject } \\
\text { before the verb } 3 . \text { Ok? }\end{array}$ \\
\hline
\end{tabular}




\begin{tabular}{|c|c|}
\hline Students' & $\begin{array}{l}\text { Excerpt 14: } \\
\mathrm{T}: \text { It's really awesome story, iya kan? } \\
\text { Bagaimana dari perusahaan kecil } \\
\text { jadi perusahhan besar seperti } \\
\text { sekarang. ( how the small company } \\
\text { becomes bigger like right now) } \\
\text { S3: ya Mem from nothing to something } \\
\text { S2: yayay from zero to hero } \\
\mathrm{T}: \text { wow amazing, thank you for your } \\
\text { small talk. Do you know small } \\
\text { talk? Basa basi ya } \\
\text { S3: hmm kalau tik tok mem apa? } \\
\text { hmmm, what aboutu tk tok mam? } \\
\text { What does it mean? ) } \\
\text { T : ah it's you } \\
\text { SS: hahahha }\end{array}$ \\
\hline $\begin{array}{l}\text { Expressing } \\
\text { disagreement in a } \\
\text { polite expression }\end{array}$ & $\begin{array}{l}\text { Excerpt 15: } \\
\mathrm{T}: \text { Ok, so everyone has finished, right? } \\
\text { Tadi saya perhatikan kalimatnya } \\
\text { sudah hampir benar semua ya, } \\
\text { tapi masih ada yang biasa lupa } \\
\text { pasangan subjectnya untuk have atau } \\
\text { has. Jadi kalau untuk have itu } \\
\text { subject apa? ( just now, I have seen } \\
\text { that your sentences are almost } \\
\text { perfect, but there are some of you } \\
\text { still forgot the couple of the subject } \\
\text { for have or has. Do you know for } \\
\text { verb have what the subject is? ) } \\
\text { SS : ayu dewi hehhhe } \\
\mathrm{T}: \text { apa itu? ( what is that? ) } \\
\text { SS : I you they and we } \\
\mathrm{T}: \text { Excellent,............. }\end{array}$ \\
\hline $\begin{array}{l}\text { Replying Students's } \\
\text { Answer without "No" }\end{array}$ & $\begin{array}{l}\text { Excerpt 16: } \\
\mathrm{T} \text { : so what is the first word? What do } \\
\text { you choose? } \\
\mathrm{S} 3: \text { told } \\
\mathrm{S} 1: \text { told } \\
\mathrm{S} 2 \text { : told juga saya pilih } \\
\mathrm{T} \text { : what does it mean? } \\
\mathrm{SS}: \text { memberitahu } \\
\mathrm{T}: \text { That is thought actually which } \\
\text { means berpikir. Verb } 3 \text { dari } \\
\text { think. }\end{array}$ \\
\hline
\end{tabular}




\begin{tabular}{|c|c|}
\hline $\begin{array}{l}\text { Telling The Next } \\
\text { Activity Using "Let's" }\end{array}$ & $\begin{array}{l}\text { Excerpt } 17 \text { : } \\
\text { T : jadi kata yang ada di situ diubah dulu ke } \\
\text { verb } 3 \text { ya baru masukkan dalam } \\
\text { kalimat. Jangan lupa pakai pola perfect } \\
\text { ya. Let's start, I give you } 7 \text { minutes to } \\
\text { do this. (so, the word given must be } \\
\text { changed first into V3 and then } \\
\text { submitted to the sentence. remember } \\
\text { use perfect form, ok.) }\end{array}$ \\
\hline $\begin{array}{l}\text { Giving Homework As } \\
\text { A "Gift" }\end{array}$ & $\begin{array}{l}\text { Excerpt } 18 \text { : } \\
\text { T: Woow very good. Well tersisa } 10 \text { menit } \\
\text { lagi sebelum kita pulang. Saya ada } \\
\text { oleh oleh buat kalian semua, mau tau } \\
\text { itu apa? ( well, remining } 10 \text { minutes } \\
\text { before going home, I have a gift for } \\
\text { you all. Do you want to know what it } \\
\text { is?) } \\
\text { S1: chocolate } \\
\text { S2: snack } \\
\text { S3: aih saya curiga ini PR ( hmmm, I beg } \\
\text { this is homework) }\end{array}$ \\
\hline
\end{tabular}

Six strategies were identified during the post teaching section. This reveals types of strategies in the post teaching as follows:

\subsubsection{Evaluation Using Appreciating Expressions}

Excerpt 13, the teacher was doing review of the previous subject. When the students can answer the question correctly, she gave positive response by saying "that's very good" and "excellent". The principle agreement and sympathy are applied by the teacher in order to maintain the students' positive face. When saying those utterances, she said it with the exaggerated of intonation and stress to appreciate the god job of the students.

\subsubsection{Praising Students' Comment to make the students be more enthusiastic}

In Excerpt 14, the teacher gave a comment of reading text. Suddenly, some of the students replied her comment by making famous quotation. To appreciate their braveness to talk and their idea, the teacher then said "wow amazing". The way of the teacher in this example shows positive politeness to encourage them to speak. By the use of this expression, the students became more enthusistic to speak, and it can be seen from their interest to talk more by making another question to the teacher. 


\subsubsection{Expressing disagreement in a polite expression to avoid discouragement}

Excerpt 15 shows the polite way of the teacher in giving feedback about the students' work. After checking her students sentences, she found that there were still some students who made mistakes. To avoid the hurt feeling, she did not directly mention the name, but she preferred to say " tadi saya perhatikan kalimatnya sudah hampir benar semua, ( just now, I have seen thay your sentences are almost correct)". The way of the teacher expresses her disagreement can be classified as a politeness where she tried to save the face of the students so they did not feel discourage in the class.

\subsubsection{Replying Students's Answer without "No" to Avoid Disagreement}

In Excerpt 16, the students have just finished doing listening activity which was filling the blank. They then continued sharing their answer. The students' answer was false, but the teacher did not say "no" or it's wrong. She then said " that's thought actually which means berpikir". It is clearly seen that the teacher here has already employed positive politeness by soften her disagreement.

\subsubsection{Telling The Next Activity Using "Let's" to maintain communication}

In Excerpt 17, the teacher used the word "let's" to move to the next activity. Similarly, the purpose of the teacher using it is to get students' understanding and cooperation. The way to motivate her students is a signaled of teacher's politeness in maintaining the communication in the class.

\subsubsection{Giving Homework As A “Gift" to intensify the students' interest}

In Excerpt 18, the situation was in the end of the teaching learning process. Before the teacher closed the class, she wanted to give homework to the students. To make it interested she said "well, remining 10 minutes before going home, I have a gift for you all. Do you want to know what it is?". The way to intensify of students' interest shows her politeness strategy by making a good story and causing the students got involve into the conversation.

\section{Discussion}

Findings show that the teacher uses 17 (seventeen) types of politeness strategies to promote effective classroom interaction in an English Conversation class. All the types of politeness strategies are effective in promoting classroom interaction. This complementary with Brown and Levinson's framework of politeness, who have introduced 15 types politeness strategies to promote effective classroom interaction (Brown and Levinson, 1987). The types of politeness strategies found in this study provide the concrete data in the forms of actual examples.

In enganging and motivating the students, positive politeness Strategy 1: Notice, attend to H ( his interest, wants, needs, goods) was used as the way to be polite to the student (excerpts 8 and 9 ). The use of that 
expression caused the student felt confidence to speak in front of the class. Brown and Levinson (1987) stated that when the speaker takes notice of aspects of hearer's condition (noticeable changes, remarkebale possessions, anything which looks as though hearer would want speaker to notice and approve of it is classified as a positive politeness. The teacher in this study has noticed her student's good and gave a positive comment to show her politeness to the student.

Giving a polite evaluation towards students' work could encourage them to speak and could maintain the students' positive face (excerpts 1314). Since the teacher used those expressions with the exaggerated of intonation and stress to appreciate the god job of the students, it can be classified as a strategy 2: Exaggerate (interest, approval, sympathy with $H$ ) referring to Brown and Levinson (1987). According to them, the exaggerated of intonation, stress, and other apects of prosodic, as well as intensifying modifiers are other features of positive politeness. A study by Hobjila (2012) entitled Positive Politeness and Negative Politeness in Didactic Comunnication-Landmarks in teaching Methodology has found that didactic communication involves the use of positive and negative politeness at each level (verbal and non verbal) in teacher and students interaction in the classroom.

Another important finding is about the use of strategy 3: intensify interest to $H$ (excerpt 2, excerpt 5, and excerpt 20). With reference to Brown and Levinson (1987), those expressions were classified as a strategy 3 where speaker share with hearer of her wants to intensify the interest, by making a good story. Furthermore, the use of quoted direct speech instead of reported speech, the use of tag question or expressions that draw hearer as participants into the conversation is another feature of this strategy. In this study, the teacher had used some expessions in order to drag her students' interest in the topic and those expressions have caused them be involved into the conversation. Based on the result study, it can be concluded that politeness encourages the mutual understanding and harmonious relationship between the teacher and the students; politeness improves teaching outcome and makes the students feel comfortable in the class; politeness causes effective and friendly interaction, and it makes the atmosphere in the class become comfortable.

The use of address term is one of positive politeness strategy (excerpts 2 and 4). Brown and Levinson (1987) introduced strategy 4 of positive politeness which is use-in-group identity markers. The words like class, guys, or calling nick name were known as "in-group-identity markers" which aims to minimize the distance between the speaker and the hearer and to build a good relation with the hearer. Leech (1983) said that the role of the politeness principle is to maintain the social equilibrum and friendly relations which enables us to assume that our interlocutors are being cooperative in the first place. A study by Sulu (2015) reports that politeness is considered to promote effective interaction between people.

Avoiding disagreement is one of positive politeness strategy introduced by Brown \& Levinson (1987) as strategy 6 Avoiding disagreement (excerpts 15 and 16). According to them instead of saying "no" to the hearer 
answer which is incorrect, it is better to hide the disagreement by using token agreement, pseudo agreement, hedging opinion, and white lies in order to maintaining the hearer face rather than damage hearer's positive face. In this study, the way of the teacher corrected her students' wrong answer has made the students did not fell discourage in the classroom. Atmowardoyo et al (2018) state that in the interaction, it is needed some rules that can adjust between the speaker and the hearer, so that the good communication can be built between them.

Brown \& Levinson (1987) maintain that positive politeness strategies give importance to the hearer's face, minimize the potential threat of FTA, and the relationship is friendly. Since joke is a technique for putting hearer at ease, it is introduced as a startegy 8: Joke in positive politeness (excerpt 10). In this study, the joke was used to acquire attention of the students and made the teaching learning process became fun. The idea of the teacher made the students felt relax and comfort in the class is also a way of politeness. This finding support the idea of Brown and Levinson (1987) which said that the choice of a strategy depends on the context of interaction, the social relationship of the speakers and the amount of imposition which the FTAs entail.

The findings also show that strategy 11: Be optimistic is used in this study (excerpt 3: You must still remember ....). When the speaker assumes that hearer wants speaker's wants for speaker (or for speaker and hearer) and will help her to obtain them. Speaker will cooperate hearer, or at least tacit claim that hearer will cooperate with speaker because it will be in their mutual interest (Brown \& Levinson; 1987). Since those expressions in this study are used to make the situation become more friendly and to make the students cooperate with her. McMohan as cited in Atmowardoyo et al ( 2018 ) said that language is an arbitary system of symbolic sounds, used by members of a society to cooperate, interact and identify themselves.

The findings also show strategy of positive politeness 12: include both speaker and hearer in the activity (excerpts 6 and 17) is applied. The use of an inclusive 'we' and 'let's' form, when speaker really means 'you' or ' $m e$ ' is considered as positive politeness (Brown \& Levinson; 1987). The sentence like 'here we go' is one of the positive politeness strategies, that is, the teacher includes herself in the learning process, which will shorten the distance from the students. Spencer-Oatey (2000) said that language strategy is the way of the speaker conveys the idea that can maintain the hearer's face to avoid miscommunication.

The last strategy of positive politeness by Brown \& Levinson which is strategy 15: give gifts to Hearer (goods, sympathy, understanding, cooperation) is also found in this study (excerpts 5, 11, and 12). Different expressions of asking someone to do are used by the teacher in order to satisfy of the students' face want. In this study the teacher avoids using imperative sentence in order to fulfill students' wants such as to be liked, to be admired, cared about, understood, and listened to. In line with this finding, Brown \& levinson (1987) said that for the same reason, positive politeness strategies are usable not only for FTA redress, but in general as 
akind of social accelerator, where speakers, in using them, indicates that they want to come closer to the hearer.

\section{Conclusion}

Based on the findings, it can be concluded that teacher has demonstrated the use of politeness 17 strategies to promote effective interaction in the classroom. With these strategies, the teacher has promoted social harmony so as the classroom interaction runs well. The findings provide real examples of the idea of positive politeness (Brown \& Levinson, 1987) that are applicable in EFL classroom of this study.

The results of this study are expected to provide benefits to realize polite communication and interaction. Specifically, the results of this study can provide actual and current information for anyone who has an interest in realizing social harmony in the classroom through polite communication and interaction. The findings can be also as a reference material and guidelines for policy makers in the education and social fields to build a society with polite character.

\section{Acknowledgement}

This work was supported by PNBP grant from State University of Makassar [Contract number:016/UN36.9/2019].

\section{Bibliographic references}

ATMOWARDOYO, H. 2018. Research methods in TEFL studies: Descriptive research, case study, error analysis, and $\mathrm{R} \& \mathrm{D}$. Journal of Language Teaching and Research, vol. 9, n. 1, pp. 197-204. DOI: http://dx.doi.org/10.17507/jltr.0901.25.

ATMOWARDOYO, H. - WEDA, S. - NASHRUDDIN. 2018. Politeness principle and its implication in EFL classroom in Indonesia. XLinguae, vol. 11, n. 4, pp. 99-112. DOI: 10.18355/XL.2018.11.04.09.

BOGDAN, R. - BIKLEN, S. Knopp. 1982. Qualitataive research for education: An introduction to theory and methods. Boston: Allyn and Bacon, Inc.

BROWN, P - LEVINSON S. 1987. Politeness: Some Universals in Language Usage, Cambridge: Cambridge University Press

GEYER, N. 2008. Discourse and politeness. New York: Continuum International Publishing Group.

GOFFMAN, E. 1967. On face-work. Interaction Ritual, pp. 5-45.

HOBJILĂ. A. 2012. Positive Politeness and Negative Politeness in Didactic Communication - Landmarks in Teaching Methodology. Procedia - Social and Behavioral Sciences, vol. 63, pp. 213-222

JOAN, C. 2002. Forms of address in Indonesian. TEFLIN Journal, vol. 50, n. 3 , pp. 15-25.

LAKOFF, R. 1973. Language and woman's place. Language in Society, vol. 2, n. 01, pp. 45-79.

LEECH, G. 1983. Principles of pragmatics. New York: Longman Inc.

NODDINGS, N. 1995. Philosophy of education. Colorado: Westview Press, Inc. 
SANJAYA, W. 2012. Strategi pembelajaran berorientasi standar proses pendidikan. Jakarta: Kencana.

SPENCER-OATEY, H. 2000. Culturally speaking: Culture, communication and politeness Theory. New York: Continuum International Publishing Group.

STRAUSS, A. - JULIET C. 1990. Basics of qualitative research: Grounded theory procedures and techniques. Newbury Park: Sage Publications.

SÜLÜ, A. 2015. Teacher's Politeness in EFL Class. International Online Journal of Education and Teaching, vol. 2, n. 4, pp. 216-221.

YULE, G. 1996. Pragmatics. Oxford: Oxford University Press.

Prof. Dr. Haryanto Atmowardoyo

English Department, Faculty of Languages and Literature State University of Makassar, Kampus UNM Parangtambung, Jl. Daeng Tata,

Makassar

Indonesia

haryanto@unm.ac.id

Assoc. Prof. Dr. Sukardi Weda

English Department Faculty of Languages and Literature State University of Makassar, Kampus UNM Parangtambung, Jl. Daeng Tata,

Makassar

Indonesia

sukardi.weda@unm.ac.id

Nurmawati

Graduate Program State University of Makassar, Kampus UNM Pettarani, Jl. AP. Pettarani,

Makassar

Indonesia

nurmawati2001@gmail.com 